\title{
Aaron J. Marcus: in pursuit of perfection
}

D r. Aaron Jacob Marcus, Professor of Medicine at Weill Cornell Medical College and distinguished physician-scientist in hematology and vascular biology, passed away on May 6, 2015 (Figure 1).

Aaron Marcus was born in 1925 in Brooklyn, New York, where he attended Boys High School (1939-1943). His formal education at the University of Virginia (1943-1944; 1946-1948) was interrupted by his service as a pharmacist's mate in the United States Navy during World War II (1944-1946). In 1953, he received his MD degree from New York Medical College, where he was elected to Alpha Omega Alpha. Following a rotating internship at Jewish Hospital of Brooklyn (1953-1954), he completed residency training in internal medicine at Montefiore Hospital (1954-1956) and served there as a fellow in hematology under Theodore H. Spaet (1956-1958). His subsequent career spanned more than fifty years. He was an attending physician and Chief of Hematology-Oncology at the New York Veterans Administration (VA) Harbor Healthcare System (1958-2015) and an attending physician at New YorkPresbyterian Hospital (1968-2015). He was Professor of Medicine (1973-2015) as well as Professor of Medicine in Pathology and Laboratory Medicine (1990-2015) at Weill Cornell Medical College. As a friend and colleague for many years at Weill Cornell Medical College, I was fortunate to know and admire both his record of scientific excellence and his generous nature.

Dr. Marcus's contributions to hematology are legendary. In his initial research papers, he carried out the first comprehensive isolation of platelet lipids and demonstrated that phosphatidylserine was unique in its ability to replace platelets in thromboplastin generation and prothrombin consumption tests $(1,2)$. These findings led to the development of the partial thromboplastin time used in clinical coagulation studies today. Based on his pioneering platelet fractionation stud- ies, he concluded that platelet membranes furnished the catalytic surface for formation of the prothrombin activator complex (3). He reported the production of platelet superoxide, which, he speculated, might shorten the life span of platelets in vitro or modulate their behavior in vivo (4). $\mathrm{He}$ demonstrated that the acetyl group of acetylsalicylic acid (aspirin) bound irreversibly to cyclooxygenase, thus inhibiting the production of platelet-specific eicosanoids

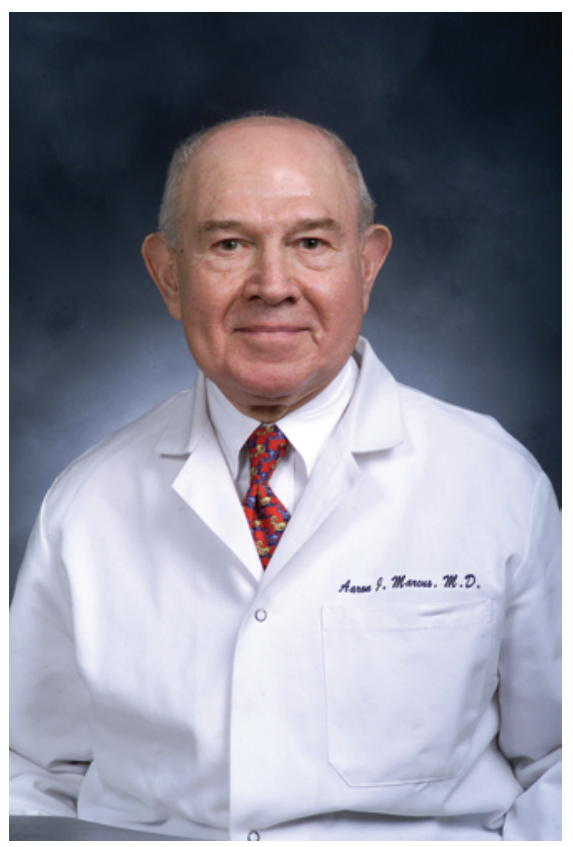

Figure 1. Aaron J. Marcus.

(5). He subsequently showed that plateletreleased lipoxygenase metabolites penetrated other cell types and were converted into new compounds, such as endothelial cell-derived prostacyclin (6) and neutrophil-derived leukotrienes (7). In his later decades, he focused on platelet-endothelial cell interactions, discovering that the latter express a cell surface ADPase (CD39) that regulates platelet reactivity (8-10) and suggesting the use of soluble ectoADPase as a therapeutic agent for plateletmediated thrombotic disorders (11). His last paper, published a few months ago, revealed that $\mathrm{CD} 39$ protects the ischemic heart by modulating renin release from intracardiac mast cells (12).

Aaron was totally dedicated to biomedical research and demanded perfection and precision in his experimental work. He eschewed offers of administrative leadership in order to pursue science, despite the long hours and diminished financial rewards that it entailed. $\mathrm{He}$ received many distinguished awards, among them the VA's Middleton Award (1987), the Henry Stratton Award from the American Society of Hematology (ASH) (1989), the Bristol-Myers-Squibb Award for Cardiovascular Research (1994), the Glorney-Raisbeck Award for Achievement in Cardiovascular Medicine from the New York Academy of Medicine (1998), and ASH's highest honor, the Wallace $\mathrm{H}$. Coulter Award for Lifetime Achievement in Hematology, to be given posthumously this year. He often joked that he wanted to die funded, and, in fact, he did, winning an NIH MERIT award at the age of 80 .

Aaron's professional style can only be characterized as generous. He religiously attended national meetings, such as the ASCI/AAP, the ASH, and the Hematology Gordon Conference. He traveled the 46 blocks from his lab at the New York VA to the main Weill Cornell campus several times per week to attend journal club, research-in-progress conferences, and other seminars. He served on NIH study sections more devotedly than anyone I know. He was constantly writing detailed letters of support or editing manuscripts and grants for colleagues and trainees. He welcomed anyone into his lab, regardless of how junior or inexperienced, and he gave abundantly of his time, energy, and reagents. When asked to serve, Aaron always "stepped up."

His generous nature was also reflected in his personal interactions with colleagues and trainees. Aaron was warm, funny, meticulous, and humble. When I was a young assistant professor, he introduced me to opera, which, as Aaron explained, was the most perfect form of art: if one read the libretto and listened to a recording before attending a performance, 
one could be transformed. He was also a master of the one-liner, often delivering a barrage of quirky aphorisms such as, "Never lie, because then you won't have to remember what you said," "Your future is guaranteed," and, my personal favorite, "You make life worth living."

Aaron Marcus loved the profession of medicine and felt that it elevated us in a way that some vocations cannot. He respected the Journal of Clinical Investigation for its rigor and for its status as the archive of medical discovery. He enjoyed the ASCI and the AAP for the sense of belonging they afforded and the opportunity to be part of something greater than oneself. I think that Aaron, like Fyodor Dostoyevsky, believed that beauty would save the world - that the perfection of a pristine experimental result, a pithy quip by Groucho Marx, or a sublime operatic aria can restore confidence and illuminate a path forward. This year, we lost not only a giant in medicine, but also the noblest of human beings. He brought out the best in us by showing what it is to be generous, kind, devoted, precise, and scholarly - elements of perfection that improve the world.

\section{Acknowledgments}

I am indebted to Joan H.F. Drosopoulos, David P. Hajjar, Deana Marcus, and Ralph L. Nachman for their critical reading of the manuscript.

\section{Katherine A. Hajjar}

Weill Cornell Medical College, New York, New York, USA. E-mail: khajjar@med. cornell.edu.

1. Marcus AJ, Spaet TH. Platelet phosphatides: their separation, identification, and clotting activity. J Clin Invest. 1958;37(12):1836-1847.

2. Marcus AJ, Ullman HL, Safier LB, Ballard HS. Platelet phosphatides: their fatty acid and aldehyde composition and activity in different clotting systems. JClin Invest. 1962;41:2198-2212.

3. Marcus AJ, Zucker-Franklin D, Safier LB, Ullman HL. Studies on human platelet granules and membranes. J Clin Invest. 1966;45(1):14-28.

4. Marcus AJ, Silk ST, Safier LB, Ullman HL. Superoxide production and reducing activity in human platelets. JClin Invest. 1977;59(1):149-158.
5. Al-Mondhiry H, Marcus AJ, Spaet TH. On the mechanism of platelet function inhibition by acetylsalicylic acid. Proc Soc Exp Biol Med. 1970;133(2):632-636.

6. Marcus AJ, Weksler BB, Jaffe EA, Broekman MJ Synthesis of prostacyclin from platelet-derived endoperoxides by cultured human endothelial cells. JClin Invest. 1980;66(5):979-986.

7. Marcus AJ, et al. Formation of leukotrienes and other hydroxy acids during platelet-neutrophil interactions in vitro. Biochem Biophys Res Commun. 1982;109(1):130-137.

8. Marcus AJ, et al. Platelet-neutrophil interactions. 12S-hydroxyeicosatetraen-1,20-dioic acid: a new eicosanoid synthesized by unstimulated neutrophils from 12S, 20-dihydroxyeicosatetraenoic acid. J Biol Chem. 1988;263(5):2223-2229.

9. Marcus AJ, et al. Inhibition of platelet function by an aspirin-insensitive endothelial cell ADPase. Thromboregulation by endothelial cells. JClin Invest. 1991;88(5):1690-1696.

10. Marcus AJ, et al. The endothelial cell ecto-ADPase responsible for inhibition of platelet function is CD39. JClin Invest. 1997;99(6):1351-1360.

11. Gayle RB, et al. Inhibition of platelet function by recombinant soluble ecto-ADPase/CD39. JClin Invest. 1998;101(9):1851-1859.

12. Aldi S, et al. E-NTPDase1/CD39 modulates renin release from heart mast cells during ischemia/reperfusion: a novel cardioprotective role. FASEB J. 2015;29(1):61-69. 